\title{
SOME AFRICAN BEES OF THE GENUS NOMIA
}

\author{
By T. D. A. Cockerell
}

The bees recorded in this paper belong to the British Museum, but will be retained by me until after the war.

Nomia semlikiana Cockerell

Uganda; Entebbe, April 12, 1914. $\quad$ (C. C. Gowdey)

Nomia matha (Cameron)

Natal; Van Reenen, Drakensberg, Dec., Jan. (R. E. Turner); Cape Province; Worcester, Jan. (Turner); Milverton, Cape Town, Jan. 1926. (Turner).

\section{Nomia heterodoxa, sp. $\mathrm{n}$.}

$\sigma^{7}$. Length about $11.5 \mathrm{~mm}$., anterior wing 10.8; black, with the scape red at base, flagellum obscurely reddened beneath, and the legs bright ferruginous; face very narrow, with pale cinereous hair, the lower part of clypeus swollen and exposed; vertex shining; pronotum with a narrow pale fringe; mesonotum and scutellum dull, not hairy, the mesonotum with linear notauli and a slender median line shining; scutellum elevated, with a pair of large bosses, shining at end; base of metathorax dull, with a shining median groove; tegulæ rather large (but not of the large type) with a light brown boss and subhyaline margins; wings very long, with a large dark brown stigma and brown nervures, the basal nervure, curved at lower end, meeting nervulus, the second submarginal cell small and very narrow; the wings are hyaline at base, but the apex is occupied by a very large black cloud, which includes the apical half of the marginal cell; legs slender and simple, the hind basitarsi very long, anterior basitarsi with very long hairs; abdomen with the basal tergite highly polished, the others mainly dull, without hairbands, the apical margins of second and third tergites reddened; fifth sternite with a black elevation on basal middle. Uganda; Mabra Forest, Chagwe, 3500-3800 ft., July 1911 (S. A. Neave). Related to 
$N$. ruwenzorica biconica Ckll., but easily distinguished by the tegulæ and the peculiar pattern of the wings.

\section{Nomia heterura Cockerell}

Gold Coast; Yapi, Dec. 1916 (J. J Simpson). A typical female, with red tegulæ. The following females have dark tegulæ, but seem to belong to the same species: Gold Coast; Yapi, Dec. 1916 (J. J. Simpson), Yapi, Sept. 1916 (Simpson). S. Nigeria; Ibadan, July 27, 1920. N. Rhodesia; Buyamungoma Boma, Jan. 14, 1911 (Silverlock).

\section{Nomia platycephala Cockerell}

Pondoland; Port St. John, March, 1924, ơ (Turner). On close comparisons, I conclude that this is probably a form of $N$. matha (Cameron), although the wings are paler than is normal for N. matha. The legs are black, and it is certainly not the same species as $N$. breviceps Ckll., described from the male in 1939 as a sub-species of $N$. matha. The sexes of $N$. platycephala are tabulated in Annals Durban Museum, Aug. 1920. In Ann. Mag. Nat. Hist., March 1935. N. matha and the apparent synonym $N$. rugicollis Friese are discussed, and it is left uncertain whether we should recognize one or more races or closely allied species.

\section{Nomia laticincta Friese}

Lonely Mine, S. Rhodesia, six females, Dec. 1913, Jan., March and April 1914 (H. Swale). The tegulæ vary in color, being in some specimens dark. As I suggested in 1939, this is probably to be regarded as a race of $N$. murinella Ckll.

\section{Nomia tricoloripes Cockerell}

British E. Africa: Masai Reserve, April 26, 1913 (T. J. Anderson). $\quad$. The female, not before known, resembles the male in most respects, but the legs are black, except the ends of the tarsi, and the front and middle knees. The hair on scutellum and postscutellum is distinctly reddish, contrasting with the pale grey of the mesonotum. This suggests $N$. murinella, from which it is easily known by the dense fulvous abdominal bands, very broad on tergites 3 to 5 . The tegulæ are translucent pale reddish, and the short flagellum is dusky red beneath. The tegulæ distinguish it from $N$. tricincta Friese, the tegulæ of which have a black boss and a hyaline margin. 


\section{Nomia victoriella Cockerell}

Uganda; between Seziwe River and Kampala, 3500-3750 ft., Aug. 27-31, 1911 (S. A. Neave). A male differs from the type by having a large red spot at each side of first tergite, as sometimes occurs in $N$. stanleyi Ckll. A typical male N. victoriella is labelled Uganda Prot., Entebbe (Forest), 3800 ft., July 5-11, 1911 (S. A. Neave).

\section{Nomia serratula Smith}

Pondoland; Port St. John, male (R. E. Turner).

\section{Nomia polytricha sp. $\mathrm{n}$.}

$0^{7}$. Length $8 \mathrm{~mm}$.; anterior wing 6.8 ; black, rather slender; mandibles black; antennæ black, with the long flagellum very faintly brownish beneath; head and thorax with abundant grayish-white hair, not dense enough on mesonotum to hide the surface; face (but not front) densely covered with coarse grayishwhite hair; vertex dull; mesonotum dull, a little shining on disc; scutellum shining, small, prominent, unarmed; upper sides of metathorax polished; tegulæ enlarged, with a very large black boss, and a broad posterior lobe, which is pallid but inconspicuous; wings long, dusky hyaline, the apical area brownish; stigma large, reddish brown, nervures pallid; lower section of basal nervure nearly straight, except that it is abruptly bent at lower end, meeting nervulus; second submarginal cell large and square, receiving recurrent nervure near the middle; legs slender and simple, with much pale hair, small joints of tarsi more or less reddened; abdomen with first and second tergites shining, the punctures very small; tergites with dull white hair-bands, on first confined to sides, on second broadly interrupted; no red hair at apex; fourth sternite with a large patch of pale reddish hair.

British East Africa; Kabeta, 6000 ft., April 11, 1918 (T. J. Anderson).

In my table this falls near $N$. kampalana Ckll., but the abdomen is narrower at base being subclaviform, and the dark tarsi and abdominal characters are distinctive. In Strand's table it runs out near $N$. parca Kohl. N. kampalana is also considerably smaller. 


\section{Nomia elgonica sp. $n$.}

$0^{7}$. Length nearly $10 \mathrm{~mm}$., anterior wing nearly 9 ; black, rather slender, antennæ black, hind tibiæ chestnut red, front and middle tibiæ reddened at end, tarsi pallid reddish; head circular seen from in front; face covered with slightly fulvescent hair, in one specimen partly denuded on clypeus; front and vertex dull; thorax with dull white hair, scanty above; mesonotum dull; scutellum hairy, dull, unarmed; area of metathorax a rather wide channel, broadly angulate in middle, with cross plicæ; sides of metathorax posteriorly dull; tegulæ rather elongated, posteriorly with a dark boss, but anteriorly broadly thin and hyaline; wings long, conspicuously reddened, but without a dark apex; stigma very pale red, nervures darker; basal nervure with lower section straight except at lower end, where it is abruptly bent and meets nervulus; second submarginal cell large, varying in width, receiving recurrent nervure beyond the middle; hind femora moderately stout, with a strong tooth beneath; hind tibiæ very broad apically; abdomen dull, without a red spot; fourth and fifth sternites shining, not tomentose.

Uganda; Mt. Kojanjero, S. W. of Elgon, 6400 ft., Aug. 7-9, 1911 (S. A. Neave). Two specimens.

In a series of similar species it is known by the red hind tibiæ, ordinary head, and entirely dull mesonotum, without punctures evident under a lens. It is to be compared with $N$. langi Ckll., which comes from Stanleyville in the Belgian Congo, and agrees in the toothed hind femora and red hind tibiæ; the wing is $7.4 \mathrm{~mm}$. long, and the mesonotum is different. There is evident affinity with the South African $N$. phenacopoda Ckll., which is smaller, and has a broad short head, and a red spot at end of abdomen. Compared with $N$. dominarum Ckll., the stigma is very much paler, and the marginal cell is shorter. N. snelli Ckll., from Zanzibar, is also related, but the hair on thorax above is quite different. 

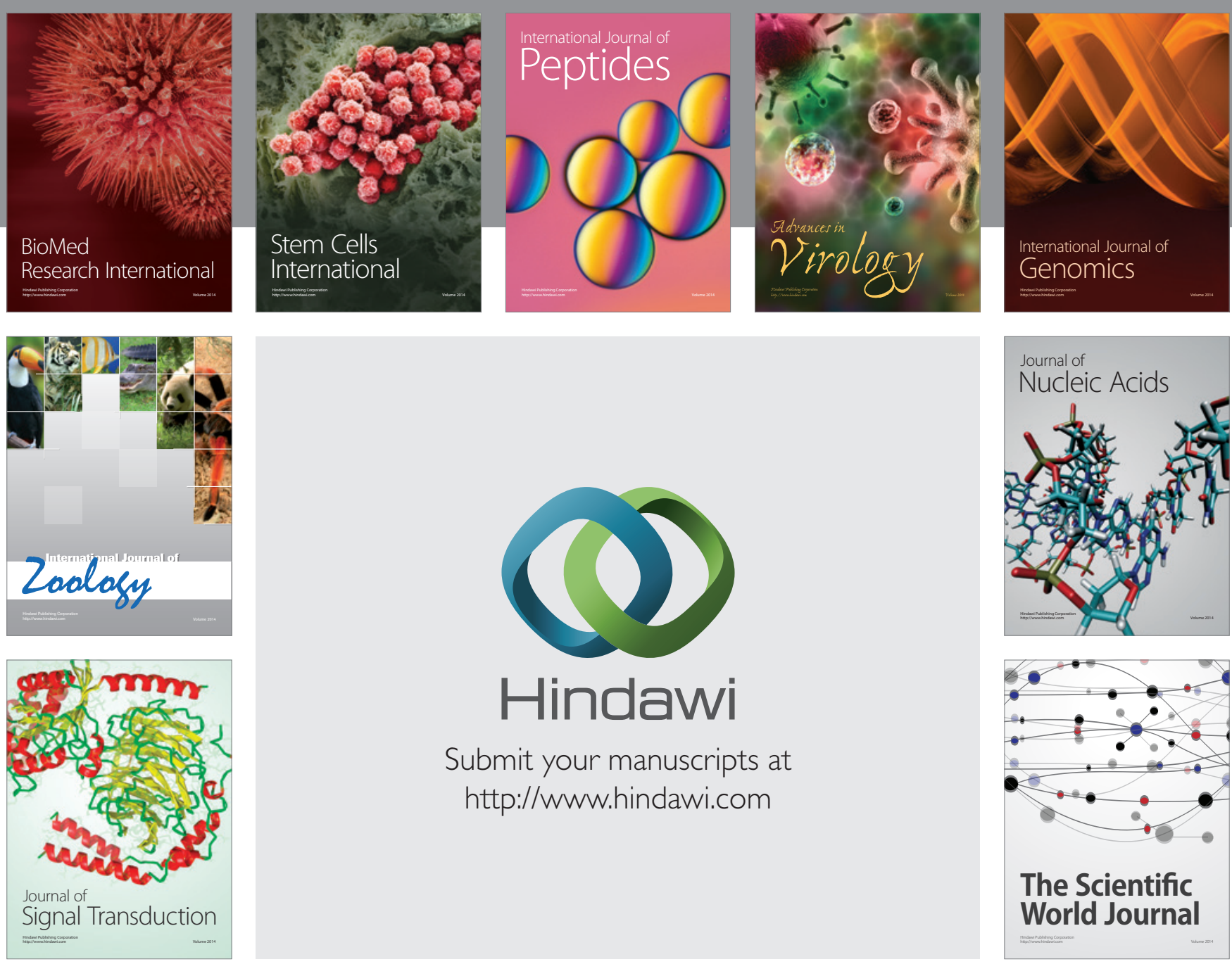

Submit your manuscripts at

http://www.hindawi.com
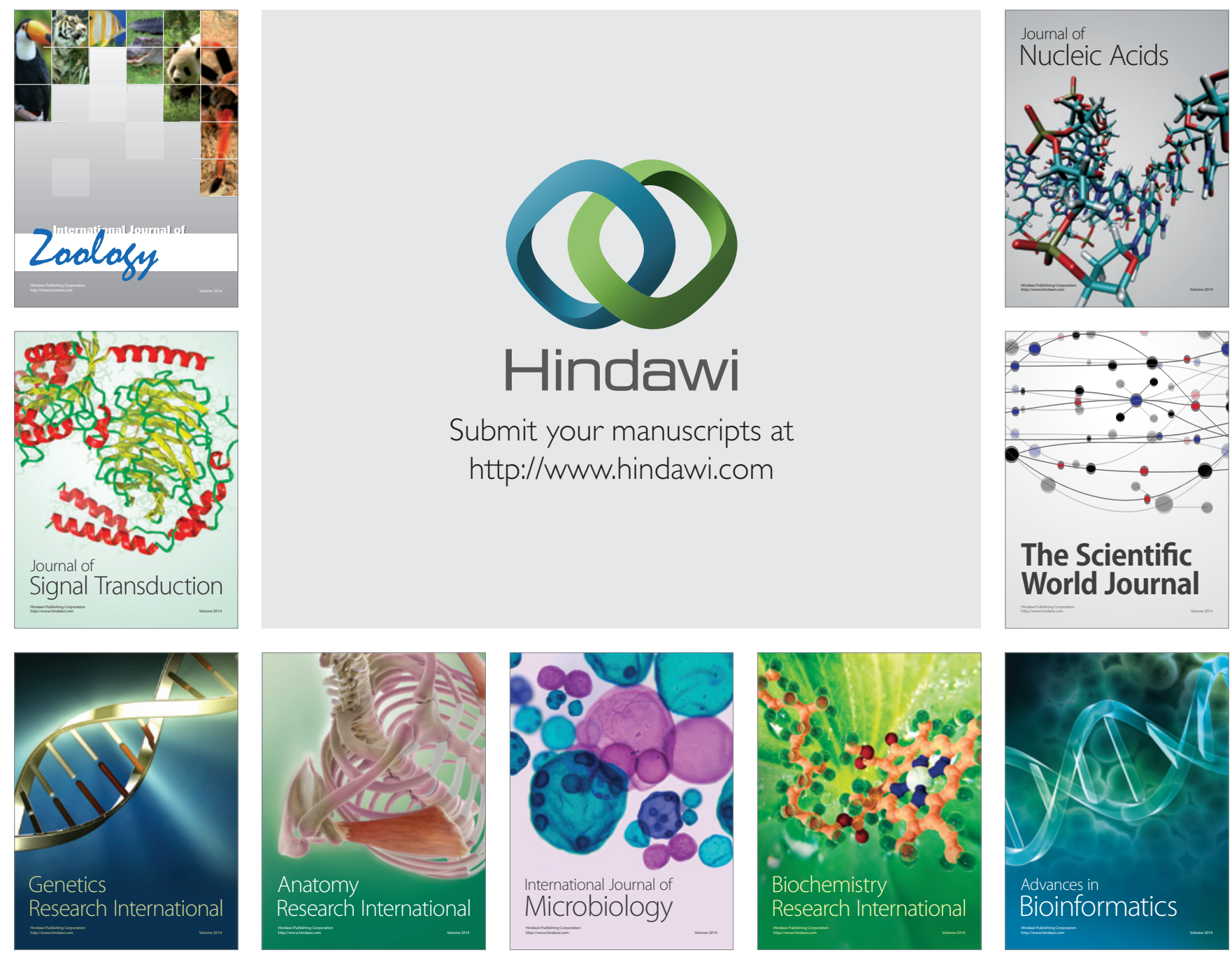

The Scientific World Journal
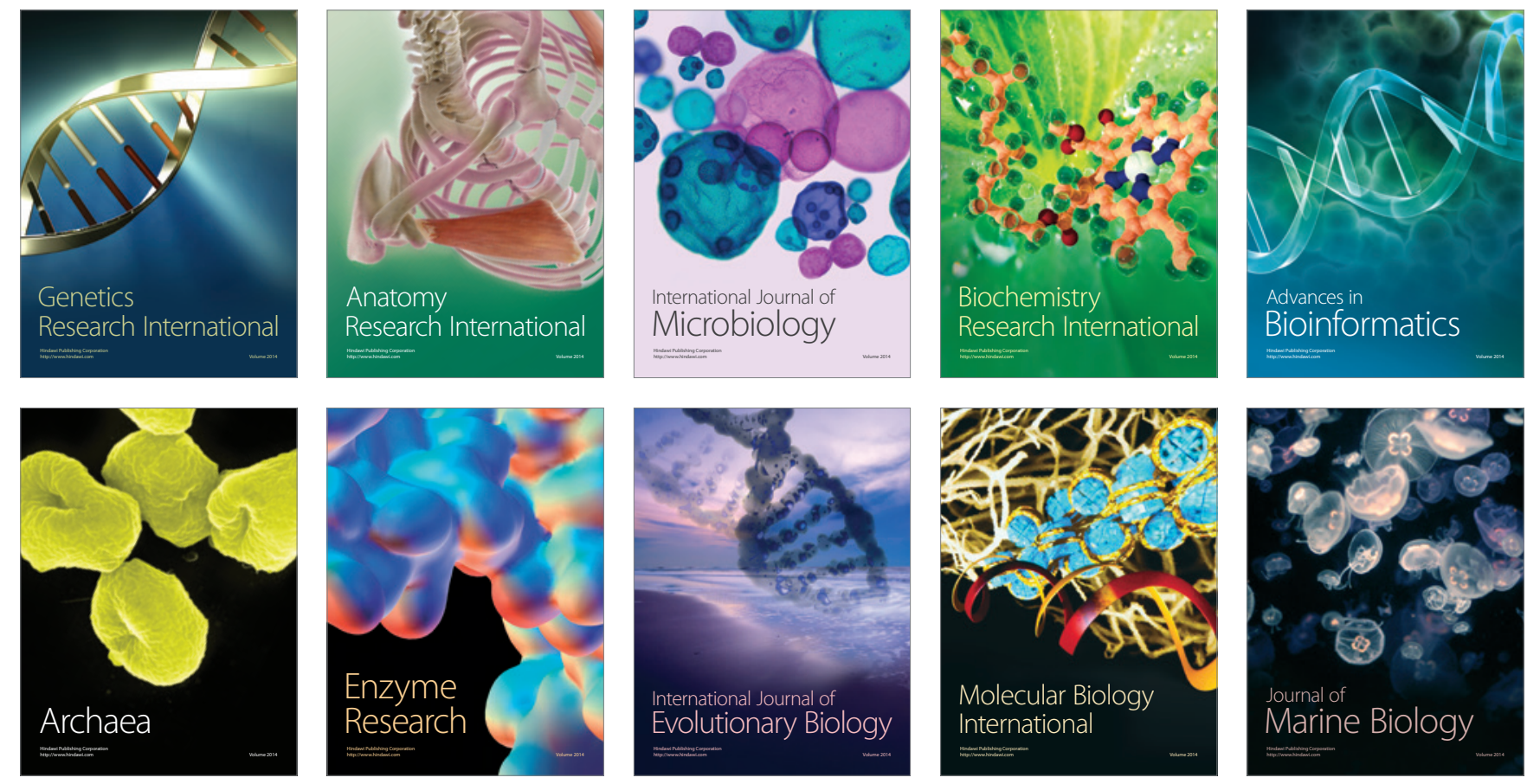